\title{
Genç erişkin bireylerde vücutta altın oran değerlendirmesi
}

\author{
Yasemin Akı Abacı ${ }^{1 *}$, Ayla Kürkçüoğlu ${ }^{2}$, Tuğçe Şençelikel $^{3}{ }_{\oplus}$ \\ ${ }^{1}$ Yaşam Ağacı Özel Eğitim ve Rehabilitasyon Merkezi, Ankara / TÜRKiYE \\ 2 Prof. Dr. | Başken Üniversitesi, Tıp Fakültesi, Anatomi Anabilim Dalı, Ankara / TÜRKIYE \\ ${ }^{3}$ Uzman | Başken Üniversitesi, Tıp Fakültesi, Biyoistatistik Anabilim Dalı, Ankara / TÜRKiYE
}

\begin{abstract}
* Sorumlu Yazar / Corresponding Author: Yasemin Akı Abacı Yaşam Ağacı Özel Eğitim ve Rehabilitasyon Merkezi

Ankara / TÜRKIYE
n.aki@hotmail.com
\end{abstract}

\section{Öz}

Altın oran uzun ylllardır mimari, sanat, matematik, geometri, tıp ve daha birçok farklı bilim dalında kullanılmaktadır. Yaptığımız araştırmalar sonucunda vücut üzerinde farklı alanlarda yapılan kimliklendirmeye yönelik, boy, yaş ve cinsiyet tahminine ait birçok antropometrik ölçüm çalışmaları bulunmasına rağmen, altın oranı araştıran ve ortaya koyan çalışmaların bulunmadığını tespit ettik. Bu çalısmanın amacı erişkin bireylerde vücutta farklı alanlardan alınacak antropometrik ölçümler ile altın oran değerini araştırmaktır. Bu çalışma yaşları 18-25 arasında değişen toplamda 77 öğrenci üzerinde gerçekleştirildi. Araştırmaya katılan tüm öğrencilerin antropometrik ölçümleri alındı. Martin tip antropometre, dijital kumpas, antropometre pergeli, T cetveli ve mezura kullanıldı. Üst ekstremiteden alınan ölçümler iki taraflı yapıldı. Literatür eșliğinde belirlenen antropometrik noktalar arasında alınan ölçümler sonrasında yapılan oran değerleri altın oran ile karşılaştırıldı. Çalışmada gövde, el ve yüz bölgesinden alınan ölçümler sonrasında yapılan oran değerlendirmeleri 1,618 ile karşılaştırıldı. Gövde bölgesinden alınan ölçümlere bağlı olarak belirlenen oranların altın oran değerine yakınlığı tespit edilemedi. Bu karşılaştırma yüz bölgesinden alınan ölçümler için yapıldığında zy-zy / sto-n değeri 1,613 $(p=0,752)$ ve tr-sn / sto-n değeri ise 1,660 $(p=0,071)$ olarak bulunmuş ve altın oran değerine yakınlık bağlamında anlamlı olarak değerlendirildi. Bu çalışmada, bedenin farklı bölgelerinden yapılan ölçümler sonucunda, elde edilen oran değerlerinin altın oran ile karşılaştırması yapılmış, elde edilen bulguların yüz bölgesi başta olmak üzere, yapılacak estetik veya rekonstrüktif yaklaşımlarda ve ortez, protez uygulamalarında yol göstermesi amaçlanmıştır.

Anahtar Sözcükler: Altın oran, 1,618, antropometri

\section{Giriş}

Altın oran, matematik ve sanatta, bir bütünün parçaları arasında gözlemlenen, uyum açısından en uygun boyutları verdiği kabul edilen geometrik ve sayısal bir orandır. İlk olarak ortaya çıkışı tam olarak bilinmese de, Mısırlıların ve Yunanlıların bu konu üzerinde yapmıs oldukları bazı çalışmalar bulunmaktadır (Hastürk, 2014).

Bilim insanları ve sanatçılar araştırmaları ve

\section{Evaluation of the golden ratio in young adult bodies}

\section{Abstract}

Golden ratio has been used for many years in architecture, art, mathematics, geometry, medicine and many other fields of science. Designs based on anthropometric data obtained from buman anatomy, which is already compatible with the golden ratio by nature, enable the creation of items for human use that are not only physically ergonomic but also perceived as aesthetically pleasing at a spiritual level. The aim of this study was to investigate the golden ratio value through anthropometric measurements of various areas of the body of adults. The study was conducted including 77 students (age, 18-25 years). Anthropometric measurements were performed using a Martin type anthropometer, sliding calliper, anthropometric compass, $T$ square and measuring tape. Golden ratios reported in the literature were compared with the golden ratios obtained through measurements. In the present study, ratios obtained and evaluated following the measurements performed on the torso, hand and face were compared with the 1.618 value. The ratios obtained from measurements of the torso were not close to the golden ratio in either sex. In the same type of comparison performed on measurements of the face, the ay-zy / sto-n value was $1.613(\mathrm{p}=0.752)$ and the tr-sn / sto-n value was $1.660(\mathrm{p}=0.071)$ in the entire group, regardless of sex; these values were significantly close to the golden ratio. In the present study, ratios obtained through measurements of different body regions were compared with the golden ratios with an aim to obtain results that could serve as a guide to plastic or reconstructive approaches_especially in the facial region-and to orthosis and prosthesis applications.

Key Words: Golden ratio, 1.618, anthropometry

eserlerini yaparken altın orana göre belirlenmiş insan bedenini ölçü olarak kullanmaktadır. Leonardo da Vinci ve Corbusier de çalışmalarına bu ölçüleri kullanarak yön vermişlerdir. Günümüzde mimarların en önemli kitaplarından birisi olan Neufert, içeriğinde altın orana göre belirlenmiş insan vücudunu esas alınmaktadır. İnsan bedeninde birçok bölgede örneğin yüzde, üst ekstremitede ve gövde de bazı ölçümler arasında oransal değerler altın oranı vermektedir (Hastürk, 
2014). İnsan bedeninin farklı bölümlerinde bulunduğu öne sürülen ve yaklaşık altın oran değerlerine uyan ideal orantı ilişkileri farklı kaynaklarda yıllardır bahsedilmiş olmasına rağmen, bilimsel anlamda araştırmalar Türk toplumu da dahil olmak üzere çok kısıtlıdır. Mevcut çalışmaların bir bölümü fotoğraflar üzerinde bir bölümü ise antropometrik ölçümler ile yapılmıstır.

İnsan parmak ölçümleri üzerinde pek çok antropometrik ölçüm çalışmaları bulunmasına rağmen altın oranı ortaya koymaya yönelik çalışmalar yoktur. Ancak Bergil (1993) bu konuda araştırması bulunan endir kişilerdendir ve başparmak hariç olmak üzere, diğer parmaklarda parmak boyunun ilk iki boğuma oranında ve orta parmak uzunluğunun serçe parmak uzunluğuna oranında altın oran varlığından söz etmiştir (Bergil, 1993). İnsan yüzünde yapılan çalışmalarda birçok standart ölçüm gösterilmekle birlikte ideal oranın var olduğu kabul edilmektedir(Wahl, 2006). Yüz güzelliğinin belli bir oran ile ilişkilendirileceğini ve yüz değerlendirmesi için bu altın oranların kullanılabileceğini ilk kez ortodontide Ricketts (1982) ortaya atmıştır. Hastürk'e (2014) göre ise insan yüzünde yer alan altın oran ölçüleri farklı şekilde verilmiştir. Örneğin yüzün boyunun yüzün genişliğine oranı, Dudak-kaşların birleşim yerinin burun boyuna oranı, yüzün boyunun çene ucu-kaşların birleşim yeri arası uzunluğuna oranı, ağı boyunun burun genişliğine oranı, burun genişiliği'nin burun delikleri arasına oranı, göz bebekleri arası mesafenin kaşlar arası mesafeye oranları yüz için altın oran parametreleri olarak kabul edilmektedir (Hastürk, 2014).

Yüz ölçümleri ile yapılan çalışmalar çekicilik konusunda önemli yer tutmaktadır. Ayrıca simetri ve asimetri araştırmaları ortodonti, plastik ve rekonstriktif cerrahi, antropoloji ve birçok bilim alanında kullanılmakla beraber, kişilerin güzellik algısında önemlidir (Porter vd., 2001). Kişiden kişiye değişen bir değer olan çekicilik alg1sının objektif değerlendirmeler ile karşılaştıran birçok çalışma yapılmıştır (Chatrath vd., 2007; Kurkcuoglu vd., 2016). Bu çalışmalar alt yüz yüksekliklerinin değerlendirilmesi, burun boy ve en oranlarının belirlenmesi, nasolabial açı ölçümü ve columella oranlarının belirlenmesine yönelik çalışmalardır (Varlik vd., 2010, Abbas v.d, 2015). Ancak yüzde altın oran araştırmasına yönelik veri eksiği bulunmaktadır.

Biz bu çalışmamızda yüz, üst ekstremite ve gövde bölgelerinden alınan ölçümler arasında altın oran değerine yakınlığı araştırdık. Belirlediğimiz parametreler mevcut literatürler eşliğinde ortaya konmuş olup, bu parametrelerin yanı sıra kendi belirlediğimiz bazı antropometrik ölçümler arasındaki oranların da 1,618 değerine yakınlığını inceledik.

\section{Gereç ve yöntem}

Bu çalışma, Başkent Üniversitesi Tıp ve Sağlık Bilimleri
Araştırma Kurulu ve Etik Kurulu tarafindan 18.04.2018 tarihinde, KA18/137 (Say1: 94603339-604.01.02) proje numarası ile onaylanması sonrasında Başkent Üniversitesi öğrencileri üzerinde tamamen gönüllülük esasına dayanarak gerçekleştirilmiştir. Araştırmada 43 kadın, 34 erkek öğrenci yer almaktadır. 18-25 yaş aralığında olan katılımciların \% 55,8'ini kadın, \% 44,15'ini erkekler oluşturmaktadır. Gövde ve yüz bölgesinden alınan ölçümler sırasında, kişilerin ayaklarının bitişik olmasına ve frankfort düzlemde (göz ve kulak kepçesi üstü aynı hizada olacak şekilde) durmalarına dikkat edilmiştir. Bireylerin vücut ağırlıkları dijital tartı ile, boy uzunlukları ise taşınabilir bir boy ölçer ile ölçülmüştür.

$\mathrm{Bu}$ çalışmada kullanılan diğer ölçüm aletleri ise şunlardır:

Martin Tip Antropometre ile yüz uzunluğu, dudak ile kaşların birleşim yeri arası mesafe, burun uzunluğu, çene ucu ile kaşların birleşim yeri arası uzunluk, saçların başlama noktası ile subnasale arası mesafe, kafa boyu uzunluğu, parmak ucu ile dirsek arası mesafe, el bileği orta parmak uzunluğu arası mesafe ölçülmüsstür.

Antropometre pergeli, yüz ölçümlerinden yüz genişliği, ağız genişliği ve burun genişliği ölçümlerinde kullanılmıştır.

Dijital kumpas, el bölgesinde yer alan ölçümlerden el ayası uzunluğu, el ayası genişliği, parmak uzunlukları (başparmak hariç), parmakların distal, orta ve proksimal boğum uzunluklarının ölçümlerinde kullanılmıştır.

T cetveli, vücut ölçümlerinden göbek ile diz arası mesafe, diz ile ayakucu arası mesafe ve el bileği dirsek arası mesafe ölçümlerinde kullanılmıştır. $T$ cetvelinin köşe kısmı sıfırdan başladığı için bu kısım baz alınarak ölçümler gerçekleştirildi.

Otuz santimlik cetvel, iz düşümler alınırken T cetveli ile yapılan ölçümlerin beraberinde kullanılmıştır.

Mezura, göbek başucu arası mesafe ölçümü alınırken kullanılmıştır.

Bu çalışmanın ilk bölümünde tüm bireylerin yaş ve cinsiyet bilgilerinin kaydı yapıldıktan sonra katılımcıların boy uzunlukları ve vücut ağırlık ölçümleri yapılmıştır. Daha sonra katılımcılardan yüz, gövde ve üst ekstremite üzerinde belirlenen farklı antropometrik noktalar arasındaki uzaklıklara ait ölçümler alınmıştır.

Vücuttan alınan tüm uzunluk ölçümleri aşağıda belirtildiği şekildedir.

Yüz bölgesinden alınan ölçümler: Kafa boyu uzunluğu, fizyonomik yüz yüksekliği, yüz genişliği, morfolojik yüz yüksekliği, üst yüz yüksekliği, burun genişliği, ağız genişliği, saçların başlama noktası-subnasale uzunluğu ve kafa boyu uzunluğu.

Gövdeden alınan ölçümler: Omuz hizası-başucu arası mesafe, göbek-başucu arası mesafe, göbek-diz arası mesafe ve diz-ayakucu arası mesafe.

Üst ekstremite bölgesinden alınan ölçümler: El 
bileği-dirsek arası uzunluk, 2., 3., 4., 5. parmak uzunluğu, Distal 2., 3., 4., 5. parmak boğum uzunluğu, Orta 2., 3., 4., 5. parmak boğum uzunluğu, Proksimal 2., 3., 4., 5. parmak boğum uzunluğu, Parmak ucu-dirsek aras1 uzunluğu.

Ilk etapta katılımcıların ayakta göbek-başucu aras1 mesafesi, göbek-diz arası mesafesi, diz-ayakucu arası mesafesi ve omuz hizası-başucu arası mesafeleri ölçülmüştür. Çalışmanın ikinci etabında, yüz ölçümleri katılımc1 sandalyede oturtularak araştırmacı kişinin karşısında olacak şekilde alınmıştır. Yapılan ölçümler sırasında katılımcılar dik oturur durumda, yüzü karşıya bakacak şekilde, çene yere paralel olacak biçimde baş pozisyonu konumlandırılmıs ve dudaklar hafif kapalı durumda tutulmuştur.

Normal büyüme ve gelişim göstermeyen, daha önce ortodontik-cerrahi tedavi geçirmiş, yüzde travma öyküsü bulunan ve konjenital defekti olan bireyler çalışmaya dâhil edilmemiştir. Kafa boyu uzunluk ölçümü yan pozisyonda alınmıştır.

Çalışmanın üçüncü etabında, yapılan üst ekstremite ölçümleri katılımcı oturur pozisyonda ve eli masanın üzerinde duracak şekilde alınmıştır. El ekleminde hareket kisitlılı̆g1, doğumsal anomalisi, travma öyküsü bulunan ve ele yönelik cerrahi bir girişim geçirmiş olan kişiler çalışma dışı bırakılmıştır. Tüm el üzerinde yapılan parmak uzunlukları ve parmak boğum uzunlukları el ayası yukarı bakar pozisyonda ve dijital kumpas kullanılarak ölçülmüştür (Resim 3). El bileği-dirsek arası mesafe ise T cetveli ve otuz santimlik cetvel kullanılarak katılımcinın ön kolu $90^{\circ}$ fleksiyonda ve dirsek $\mathrm{T}$ cetvelinin üzerine gelecek şekilde ölçülmüştür.

Yüz bölgesinde yer alan birçok antropometrik referans noktası bulunmaktadır. Bu çalışmada kullanılan ölçümler öncesinde belirlenen antropometrik referans noktaları Resim 1 ve 2'de gösterilmiş ve Tablo 1'de tarif edilmiştir.

$\mathrm{Bu}$ çalışmada gövde ve üst ekstremite

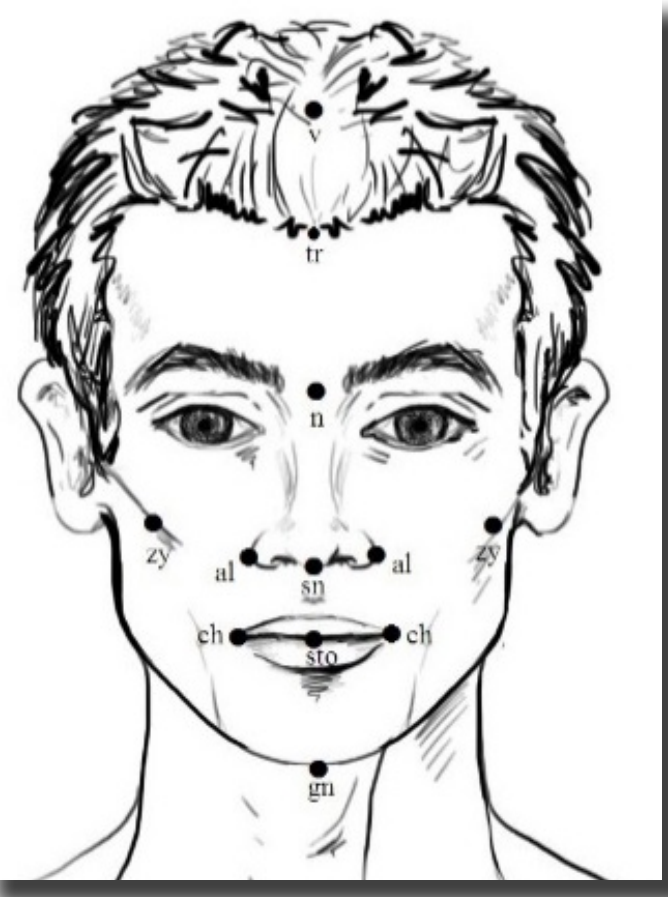

Resim 1. Yüz bölgesinde kullanılan referans noktaları. v: verteks, tri: trichion, n: nasion, zy: sygion, al: alare, sn: subnasale, ch: chelion, sto: stomion, gn: gnathion

bölgesinde altın oran ölçümleri için kullanılan uzunluk ölçümleri Tablo 2'de tarif edilmiş olup, Resim 3'de gösterilmiştir.

\section{İstatistiksel yöntem}

Çalışmada tanımlayıcı istatistik olarak parametrik test varsayımları sağlanıyorsa ortalama \pm standart sapma, sağlanmiyorsa medyan (minimum-maksimum) verilmiştir. Alınan ölçümlerin 1,618 (altın oran) değerinden farklı olup olmadiğ 1 parametrik test varsayımları sağlandığında "Tek Örneklem t Testi" sağlanmadiğında "Tek Örnek Wilcoxon İşaret Testi" kullanılmıştır. Araştırmacının aldığı birinci ve ikinci ölçüm arasındaki güvenirliğin değerlendirilmesinde Sınıfiçi Korelasyon Katsayısı (Intraclass Correlation

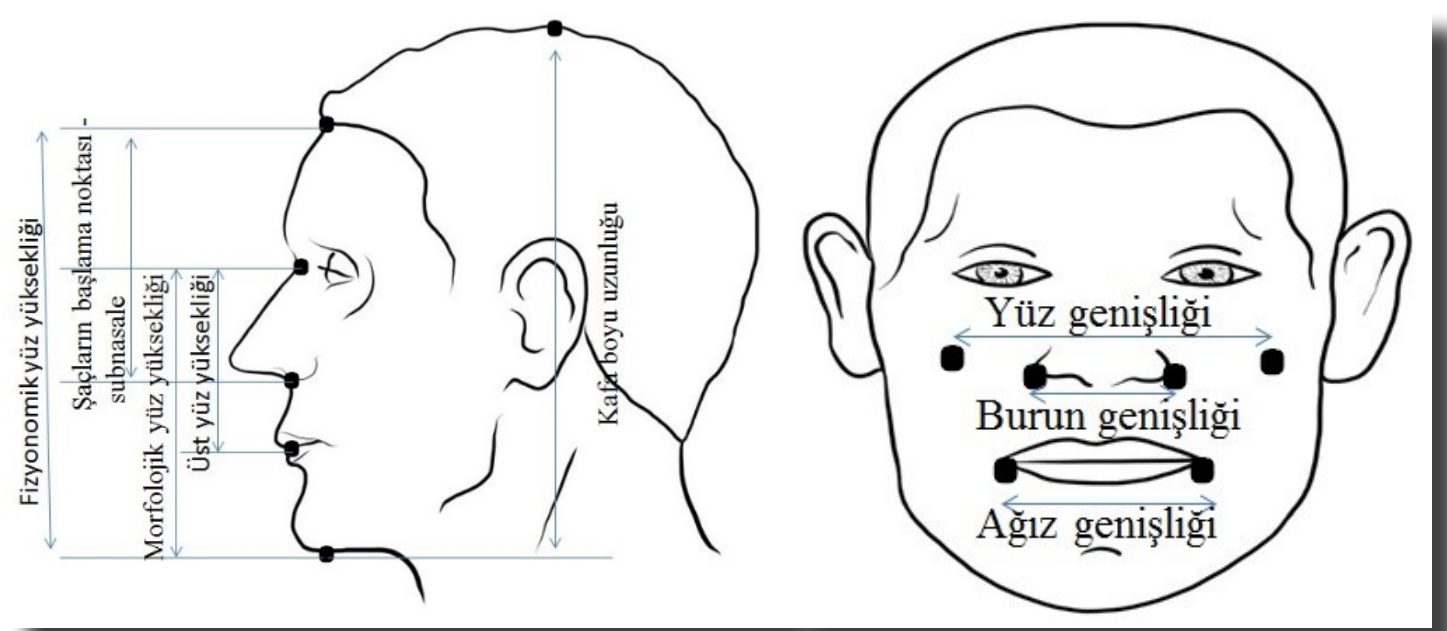

Resim 2. Yüz üzerinde ölçümü yapılan uzunluklar 
Tablo 1. Yüz bölgesi üzerinde k1llanılan referans noktaları ve ölçümler ile tanımları

\begin{tabular}{|c|c|}
\hline Noktalar/Ölçümler & Tanımlar \\
\hline Verteks (v) & Baş Frankfort düzleminde tutulduğunda orta sagital düzlemde başın en üst kısmı, başın tepesi \\
\hline Trichion (tr) & Yüze ön bakışta alın ile saçlı derinin birleşme noktası, alında saç hattının başladığı orta nokta \\
\hline Nasion (n) & Nasofrontal suturun orta noktasi \\
\hline Zygion (zy) & Yanakta elmacık kemikleri üzerinde zygomatik arkın yüze önden bakışla en dışta kalan nokta \\
\hline Alare (al) & Burun kanatlarının en dış noktası \\
\hline Subnasale (sn) & $\begin{array}{l}\text { Septum nasi alt noktası, columella tabanının nasal septum alt sinırının ve üst dudak yüzeyinin } \\
\text { birleşme açısının orta tepe noktası }\end{array}$ \\
\hline Stomion (sto) & Orta hatta üst ve alt dudakların temas ettikleri tam orta nokta \\
\hline Cheilion (ch) & Her iki tarafta ağı köşesi noktası, üst ve alt dudak birleşim noktası \\
\hline Gnathion (gn) & Mandibula alt kenarnda en alt orta nokta \\
\hline Kafa boyu uzunluğu (v-gn) & Verteks ile gnathion aras1 uzunluk \\
\hline Fizyonomik yüz yüksekliği (tr-gn) & Trichion ve gnathion aras1 uzunluk \\
\hline $\begin{array}{l}\text { Yüz genişliği (Bizigomatik genişlik/ } \\
\qquad z y-z y)\end{array}$ & $\begin{array}{l}\text { Zigomatik arkların maksimum lateral noktaları arasındaki uzunluk, sağ ve sol zygion arası } \\
\text { uzunluk }\end{array}$ \\
\hline Morfolojik yüz yüksekliği (n-gn) & Nasion ve gnathion arası uzunluk \\
\hline Üst yüz yüksekliği (n-sto) & Nasion ve stomion arasi uzunluk \\
\hline Burun genişliği (al-al) & Ala nasi'ler arası uzunluk \\
\hline Ağız genişliği $(c h-c h)$ & Chellion noktalar (ağız köşeleri - commissura laborium) arası uzunluk \\
\hline Saçların başlama noktasi-subnasale (tr-sn) & Trichion ve subnasale aras1 uzunluk \\
\hline
\end{tabular}

Tablo 2. Gövde ve üst ekstremite üzerinde yapılan ölçümler için kullanılan referans noktaları ve ölçümler ile tanımları

\begin{tabular}{|c|c|}
\hline Noktalar/Ölçümler & Tanımlar \\
\hline Omphalion (umbilikus) & Göbek deliğii, göbeğin orta noktası \\
\hline Suprasternale (incisura jugularis) & Sternumdaki jugular çentiğin en alt orta noktası \\
\hline Tibiale & Tibianın medial üst yüzeyindeki en üst nokta* \\
\hline Acropodion & Ayak başparmak en uç noktası \\
\hline Dactylion & El orta parmak distal ucu \\
\hline Olecranon (dirsek çıkıntısı) & Dirsek bölgesindeki kemik çıkıntısı \\
\hline Göbek-başucu & Omphalion ile verteks arası mesafe \\
\hline Omuz hizası-başucu & Suprasternale ile verteks arasi mesafe \\
\hline Göbek-diz ortası & Omphalion ile tibialelerin orta noktası izdüşümü arası mesafe \\
\hline Diz ortas-ayakucu & Tibialelerin orta noktası izdüşümü ile acropodion arası mesafe \\
\hline El orta parmak distal ucu-dirsek & Dactylion-olecranon aras1 mesafe \\
\hline El bileği-dirsek & Distal el bileği çizgisi ile olecranon arası mesafe \\
\hline El uzunluğu & Distal el bileği çizgisi ile el orta parmak distal ucu arası mesafe \\
\hline Parmak uzunlukları (II-V) & $\begin{array}{l}\text { Her parmağın distal ucunun tepe noktası ile aynı parmağın proksimal fleksiyon çizgisi orta } \\
\text { noktası arasındaki mesafe }\end{array}$ \\
\hline Distal ilk boğum uzunlukları (II-V) & $\begin{array}{l}\text { Her parmağın distal boğumunda yer alan proksimal çizgi ile aynı parmağın distal tepe noktası } \\
\text { arası mesafe }\end{array}$ \\
\hline Orta boğum uzunluğu (II-V) & $\begin{array}{l}\text { Her parmağın orta boğumunda yer alan proksimal çizgi ile aynı boğumun distal çizgisi arası } \\
\text { mesafe }\end{array}$ \\
\hline Proksimal boğum uzunluğu (II-V) & $\begin{array}{l}\text { Her parmağın proksimal boğumunda yer alan proksimal çizgi ile aynı boğumun distal çizgisi } \\
\text { arası mesafe }\end{array}$ \\
\hline
\end{tabular}

* Yapılan ölçümlerde her iki tibiale noktasının birleşimindeki orta noktadan ölçümler gerçekleştirilmiştir. 


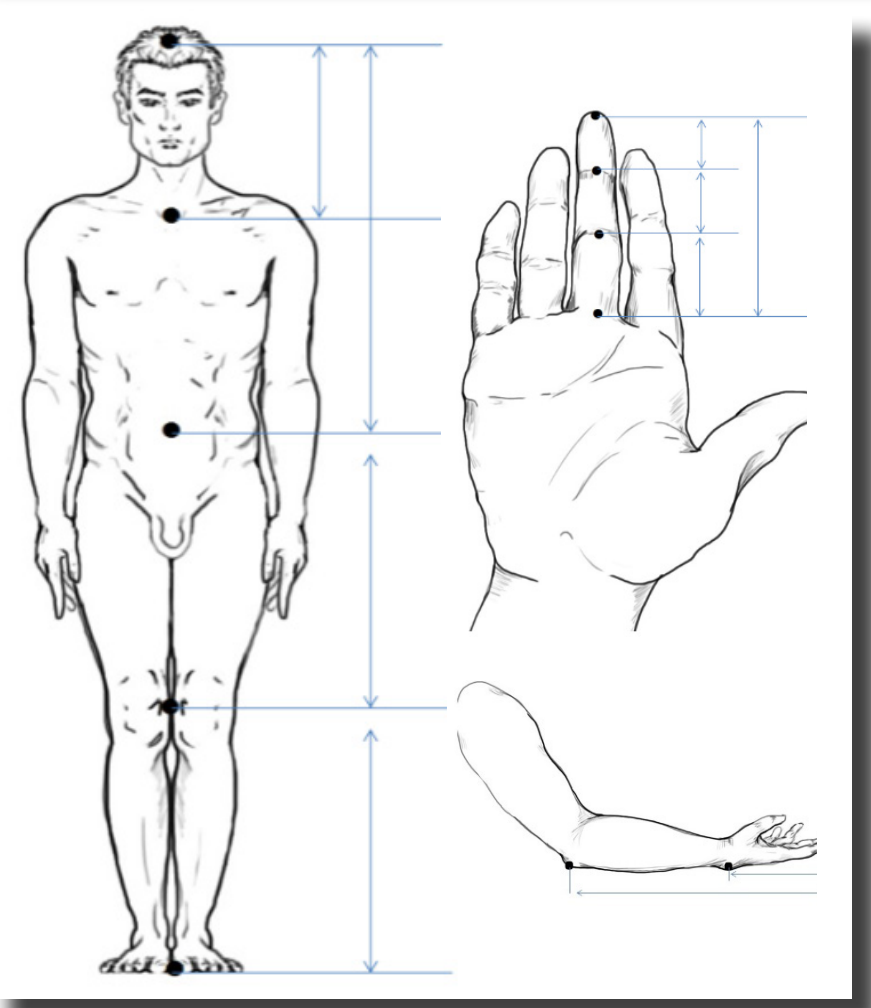

Resim 3. Gövde ve üst ekstremite bölgesinde bulunan referans noktaları ve alınan ölçümler

Coefficient) kullanılmıştır. Analizlerde I. tip hata olasılı̆̆g 0,05 olarak belirlenmiştir. Analizlerin tamamı IBM SPSS 25 kullanılarak yapılmıştır.

\section{Bulgular}

Çalışmamıza Ankara Başkent Üniversitesinde öğrenim gören 34 erkek (\%44,2), 43 kadin $(\% 55,8)$ toplam 77 öğrenci katılmıştır. Yaş ortalaması erkeklerde 20,3 $\pm 2,14$ yıl kadınlarda ise 20,1 $\pm 2,08$ yıldır. Erkek katılımciların boy ve kilo ortalama değerleri sirasiyla 177,6 $\pm 8,05$ $\mathrm{cm}$ ve $80,06 \pm 13,87 \mathrm{~kg}$ iken, kadinların boy ve kilo değerleri sirasiyla $163,4 \pm 5,33 \mathrm{~cm}$ ve $61,4 \pm 9,6 \mathrm{~kg}$ olarak değerlendirilmiştir.

Alınan ölçümlerin \%10’unun ikinci ölçümü aynı araştırmacı tarafindan yapılmış ve ilk ölçümler ile karşılaştırması yapılmıştır. İlk ve ikinci ölçümler arasında tutarlı bir sonuç olup olmadığı ICC (Intraclass Correlation Coefficient) sınıf içi korelasyon katsayısı ile değerlendirilmiştir (0,95-1,00 mükemmel, 0,85-0,94 yüksek, 0,70-0,84 orta, 0,00-0,69 kabul edilemez). Bu bağlamda sol taraf 3. parmak proksimal boğum (ICC $=0,375)$, sol taraf 5. parmak proksimal boğum (ICC $=0,480)$, sağ taraf 5 . parmak proksimal boğum $(\mathrm{ICC}=0,480)$ ve üst yüz yüksekliği uzunluğu (ICC $=0,615)$ ölçümleri tutarsız olmasının yanı sıra diğer tüm ölçümlerin mükemmel ve yüksek ICC değerine sahip olduğu belirlenmiştir.

Çalışmanın ilk aşamasında belirlenen antropometrik ölçümler sonrası yüz, gövde ve üst ekstremitede yapılan ölçümler ve altın oran değerlendirmelerine ait Tablo 3'de verilmiştir.

Yapılan tüm antropometrik ölçümler milimetre (mm) cinsinden ölçülmüss ve oranlamalar sağ-sol çift taraflı olarak yapılmıştır. Ayrıca kadın ve erkekten elde edilen tüm bulgular altın oran değeri ile karşılaştırılmış olup, yüz, gövde ve üst ekstremite bölgelerine ait ayr1 tablolar hâlinde sunulmuştur.

Yüz bölgesinden alınan ölçümlerin Tablo 4'de belirtilen oranları, 1,618 ile karşılaştırıldığında tüm grupta cinsiyet ayrım1 gözetmeksizin $(\operatorname{tr}-g n) /(z y-z y)$, $(z y-z y) /(s t o-n)$ ve $(t r-s n) /(s t o-n)$ oran1 1,618 altin oran değerine benzer bulunmuştur (sirasiyla $p=0,024$, $p=0,752 ; p=0,071$ ) (Tablo 4).

Altın orana yakınlık bakımından yüz bölgesinde yapılan değerlendirmede kadın ve erkekler ayrı ayrı incelenmiş ve Tablo 5 ve Tablo 6'da gösterilmiştir. Kadinlarda $(\operatorname{tr}-g n) /(\{y-z y)$ oran1, $(z y-z y) /(s t o-n)$ oranı ve

Tablo 3. Çalışmada kullanılan tüm altın oran ölçümleri

\begin{tabular}{|c|}
\hline Ölçümler \\
\hline Fizyonomik yüz yüksekliği (tr-gn) / Yüz genişliği (zy-zy) \\
\hline Fizyonomik yüz yüksekliği (tr-gn) / Morfolojik yüz yüksekliği $(n-g n)$ \\
\hline Fizyonomik yüz yüksekliğ $i(t r-g n)$ / Saçların başlama noktası - subnasale (tr-sn) \\
\hline A ğ1z genişliğgi $(c h-c b)$ / Burun genişliği (al-al) \\
\hline Yüz genişliği (žy-zyy) / Üst yüz yüksekliği (n-sto) \\
\hline Morfolojik yüz yüksekliği (n-gn) / Üst yüz yüksekliği (n-sto) \\
\hline Saçların başlama noktası - subnasale (tr-sn) / Üst yüz yüksekliği (n-sto) \\
\hline Omuz hizası- başucu / Kafa boyu uzunluğu \\
\hline Göbek - başucu / Omuz hizası- başucu \\
\hline Göbek - diz ortası / Diz ortas1 - ayakucu \\
\hline Parmak ucu - dirsek / El bileği - dirsek \\
\hline Parmak uzunluğu / Proksimal ilk iki boğum uzunluğu \\
\hline Parmak uzunluğu / Distal ilk iki boğum uzunluğu \\
\hline Orta parmak uzunluğu / Serçe parmak uzunluğu \\
\hline
\end{tabular}


Akı Abacı vd.| Antropoloji (40) (2020)

Tablo 4. Yüz bölgesinden alınan uzunluk ölçümlerinin tüm grup için 1,618 ile karşıllaştırılmış analiz sonuçları

\begin{tabular}{|c|c|c|}
\hline \multicolumn{2}{|c|}{ Yüzdeki ölçüm oranları } & $p$ \\
\hline$(\operatorname{tr}-g n) /(z y-z y)$ & $1,59(1,37-2,46)$ & $0,024^{1}$ \\
\hline$(\operatorname{tr}-g n) /(n-g n)$ & $1,52(1,35-2,30)$ & $<0,001^{1}$ \\
\hline$(t r-g n) /(t r-s n)$ & $1,55(0,97-2,69)$ & $<0,001^{1}$ \\
\hline$(c h-c h) /(a l-a b)$ & $1,40(1,15-1,95)$ & $<0,001^{1}$ \\
\hline$(z y-z y) /(s t o-n)$ & $1,613 \pm 0,144$ & $0,752^{2}$ \\
\hline$(g n-n) /(s t o-n)$ & $1,67(1,04-1,93)$ & $<0,001^{1}$ \\
\hline$(t r-g n) /(t r-s n)$ & $1,55(0,97-2,69)$ & $<0,001^{1}$ \\
\hline$(t r-s n) /(s t o-n)$ & $1,66(0,91-2,41)$ & $\mathbf{0 , 0 7 1 ^ { 1 }}$ \\
\hline
\end{tabular}

${ }^{1}$ Tek Örnek Wilcoxon İşaret Testi, Medyan (Minimum-Maksimum)

${ }^{2}$ Tek Örnek t Testi, Ortalama \pm Standart Sapma

Tablo 5. Kadınların yüz bölgesinden alınan uzunluk ölçümlerinin 1,618 ile karșılaștırılmıș analiz sonuçları

\begin{tabular}{|c|c|c|}
\hline \multicolumn{2}{|c|}{ Yüzdeki ölçüm oranları (Kadın) } & \multirow{2}{*}{$\frac{p}{0,260^{2}}$} \\
\hline$(\operatorname{tr}-g n) /(z y-z y)$ & $1,601 \pm 0,097$ & \\
\hline$(\operatorname{tr}-g n) /(n-g n)$ & $1,290 \pm 0,072$ & $<0,001^{2}$ \\
\hline$(t r-g n) /(t r-s n)$ & $1,525 \pm 0,065$ & $<0,001^{2}$ \\
\hline$(c b-c h) /(a l-a l)$ & $1,42(1,19-1,95)$ & $<0,001^{1}$ \\
\hline$(\mathfrak{z} y-z y) /(s t o-n)$ & $1,59 \pm 0,12$ & $0,278^{2}$ \\
\hline$(g n-n) /(s t o-n)$ & $1,67 \pm 0,084$ & $<0,001^{2}$ \\
\hline$(\operatorname{tr}-g n) /(\operatorname{tr}-s n)$ & $1,52(1,44-2,69)$ & $<0,001^{1}$ \\
\hline$(t r-s n) /(s t o-n)$ & $1,66(0,91-1,87)$ & $0,103^{1}$ \\
\hline \multicolumn{3}{|c|}{${ }^{1}$ Tek Örnek Wilcoxon İşaret Testi, Medyan (Minimum-Maksimum) } \\
\hline Tek Örnek t Testi, & \pm Standart Sapma & \\
\hline
\end{tabular}

Tablo 6. Erkeklerin yüz bölgesinden alınan uzunluk ölçümlerinin 1,618 ile karşılaştırılmış analiz sonuçları

\begin{tabular}{|c|c|c|}
\hline \multicolumn{2}{|c|}{ Yüzdeki ölçüm oranları (Erkek) } & $p$ \\
\hline$(\operatorname{tr}-g n) /(z y-z y)$ & $1,576(1,37-2,46)$ & $0,064^{1}$ \\
\hline$(\operatorname{tr}-g n) /(n-g n)$ & $1,526(1,35-2,30)$ & $<0,001^{1}$ \\
\hline$(\operatorname{tr}-g n) /(\operatorname{tr}-s n)$ & $1,579(0,97-2,15)$ & $<0,001^{1}$ \\
\hline$(c b-c b) /(a l-a b)$ & $1,41 \pm 0,162$ & $<0,001^{2}$ \\
\hline$(z y-z y) /(s t o-n)$ & $1,64(0,96-1,94)$ & $0,248^{1}$ \\
\hline$(g n-n) /(s t o-n)$ & $1,69(1,04-1,93)$ & $<0,001^{1}$ \\
\hline$(\operatorname{tr}-g n) /(\operatorname{tr}-s n)$ & $1,57(0,97-2,15)$ & $0,110^{1}$ \\
\hline$(t r-s n) /(s t o-n)$ & $1,66(0,96-2,41)$ & $0,379^{1}$ \\
\hline
\end{tabular}

${ }^{1}$ Tek Örnek Wilcoxon İşaret Testi, Medyan (Minimum-Maksimum)

${ }^{2}$ Tek Örnek t Testi, Ortalama \pm Standart Sapma

$($ tr-sn)/(sto-n) oran1 1,618 altın oran değerine benzer bulunmuştur (s1rasiyla $p=0,260 ; p=0,278 ; p=0,103$ ).

Erkeklerde yüz bölgesinde yapılan ölçümler sonrası

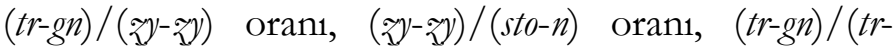
$s n)$ oran1 ve $(t r-s n) /(s t o-n)$ oran1 1,618'e benzer olarak bulunmuştur (sırasılyla $p=0,064 ; p=0,248 ; p=0,379$ ).

Gövde'den alınan ölçümlerin Tablo 7'de belirtilen oranları 1,618 ile karşılaştırıldığında tüm grupta cinsiyet ayrımı gözetmeksizin altın oran’a benzer bulunamamıştır.

Altın orana yakınlık bakımından gövdede yapılan değerlendirmede her iki cinsiyet sonuçları ayr1 ayr1 incelenmiş ve tablo 8 ve tablo 9'da gösterilmiştir. Bu sonuçlara göre kadınlarda elde edilen sonuçlar altın oran bakımından benzer bulunamamıştır.

Erkeklerde gövdede yapılan ölçümler sonrası elde edilen oranlar de 1,618'e benzer olmadığı görülmüștür (Tablo 9).

Üst ekstremite'den alınan ölçümler sonrasında bulunun oranlar Tablo 10'da belirtildiği şekilde olup, tüm grupta cinsiyet ayrımı gözetmeksizin sağ ve sol taraf 5. parmak/proksimal ilk iki boğum değeri altın oran açısından benzer olarak değerlendirilmiştir (sırasıyla $p=0,304 ; p=0,249)$.

Altın orana yakınlık bakımından üst ekstremiteden 
Akı Abacı vd.| Antropoloji (40) (2020)

Tablo 7. Gövdeden alınan uzunluk ölçümlerinin tüm grup için 1,618 ile karşılaştırılmış analiz sonuçları

\begin{tabular}{ccc}
\hline Vücut ölçüm oranları & $\boldsymbol{p}$ \\
\hline Omuz hizası-başucu / Kafa boyu uzunluğu & $1,27(0,56-1,93)$ & $<0,001^{1}$ \\
Göbek-başucu / Omuz hizası-başucu & $2,22(0,25-2,42)$ & $<0,001^{1}$ \\
Göbek diz ortası / Diz ortası-ayakucu & $1,25(0,13-12,50)$ & $\mathbf{0 , 0 7 1}^{1}$ \\
\hline${ }^{1}$ Tek Örnek Wilcoxon İşaret Testi, Medyan (Minimum-Maksimum) & \\
\hline
\end{tabular}

Tablo 8. Kadın gövdelerinden alınan uzunluk ölçümlerinin 1,618 ile karşılaştırılmıș analiz sonuçları

\begin{tabular}{clc}
\hline Vücut ölçüm oranları (Kadın) & & $\boldsymbol{p}$ \\
\hline Omuz hizası-başucu / Kafa boyu uzunluğu & $1,271 \pm 0,059$ & $<0,001^{2}$ \\
Göbek-başucu / Omuz hizası-başucu & $2,214(0,25-2,41)$ & $<0,001^{1}$ \\
Göbek diz ortası / Diz ortası-ayakucu & $1,269(0,13-1,75)$ & $<0,001^{1}$ \\
\hline
\end{tabular}

${ }^{1}$ Tek Örnek Wilcoxon İşaret Testi, Medyan (Minimum-Maksimum)

${ }^{2}$ Tek Örnek t Testi, Ortalama \pm Standart Sapma

Tablo 9. Erkek gövdelerinden alınan uzunluk ölçümlerinin 1,618 ile karşılaştırılmış analiz sonuçları

\begin{tabular}{clc}
\hline Vücut ölçüm oranları (Erkek) & & $\boldsymbol{p}$ \\
\hline Omuz hizası-başucu / Kafa boyu uzunluğu & $1,271 \pm 0,059$ & $<0,001^{2}$ \\
Göbek-başucu / Omuz hizas1-başucu & $2,214(0,25-2,41)$ & $<0,001^{1}$ \\
Göbek diz ortası / Diz ortası-ayakucu & $1,269(0,13-1,75)$ & $<0,001^{1}$ \\
\hline
\end{tabular}

${ }^{1}$ Tek Örnek Wilcoxon İşaret Testi, Medyan (Minimum-Maksimum)

${ }^{2}$ Tek Örnek t Testi, Ortalama \pm Standart Sapma

yapılan değerlendirmelerde cinsiyetler ayr1 ayr1 incelenmiş ve tablo 11 ve tablo 12 de gösterilmiştir. Kadınlarda sağ ve sol taraf 5. parmak/proksimal ilk iki boğum uzunluğu altın oran açısından benzer olarak değerlendirilmiştir (sırasılla $p=0,981 ; p=0,453$ ) (Tablo 4). Sağ ve sol taraf 2., 3. ve 4. parmak oranlarinın da altın oran benzer olduğu bulunmuştur.

Erkeklerde yapılan ölçümler de kadınlara benzerlik göstermiş ve sağ ve sol taraf 5. parmak/proksimal ilk iki boğum uzunluğu altın oran açısından benzer olarak değerlendirilmiştir (sırasıyla $p=0,044 ; p=0,381$ ) (Tablo 4) Ayrıca parmak ucu-dirsek / el bileği-dirsek oranında sonucun her iki taraf için de altın oran değerine yakınlığ1 dikkat çekmiştir.

\section{Tartışma}

Altın oran en yalın anlamıyla "göz nizamının oranı" olarak tanımlanabilir (Deviren, 2010). Antik dönemden günümüze altın oran sanatç1, tasarımc1 ve bilim insanlarının ilgisini çekmiş ve bu konuda birçok araștırmalar yapmalarına neden olmuștur. $\mathrm{Bu}$ araştırmalar 1şı̆̆ında insan bedeninin anatomisinin tüm hatlarıyla incelenmesi sonucu ideal bazı ölçüler elde edilmiştir. Bu da altın oranı güzeli tasvir etmek amacıyla sanat, tıp, mimari gibi birçok bilim dalında kullanılan ölçütlerden biri konumuna getirmiştir (Hastürk, 2014). Altın oran doğada var olan canlıların anatomik yapısında bulunmakta ve yapısal özelliklerin ortaya konmasinda etkili olmaktadır. İnsanlara yönelik günlük hayatta kullanım amaçlı tasarımlar yapilırken bu orandan yararlanılmaktadır (Güzel, 2013; Hastürk, 2014). Aynı zamanda vücut üzerinde yapılan antropometrik ölçümler bize değişik düzeylerde vücut kompozisyonu hakkında bilgi vermektedir. Aynı zamanda hastalık ve yaşlanma süreçlerinde antropometrik değişikliklerin incelenmesi normal durum ile patolojik durumların değerlendirilmesi konusunda farklı anlam taşımaktadır (Wang vd., 1992). Altın oranın varlığ1 ve önemi konusunda farklı görüşler söz konusudur. Örneğin Stanford Üniversitesi'nde matematik profesörü olan Keith Devlin altın oran konusundaki görüşünü "Gerçek dünyadaki herhangi bir şeyin, kesin konuşmak gerekirse, altın orana uyması mümkün değil, çünkü altın oran irrasyonel bir sayıdır" şeklinde ifade etmektedir. Devlin, dünyada mükemmel bir çemberi bulmak nasıl mümkün değilse, altın oranın da gerçek dünyada herhangi bir nesnede her zaman biraz eksik kalacağ1 ve çoğu zaman kurala uymayacağ1 kanısındadır. Bununla birlikte günümüz tasarımciların birçoğu da bu oranın kullanışlı olmadığ fikrine sahiptir (Brownlee, 2015).

İnsan bedeni üzerinde yapılan altın orana yönelik sınırlı çalışmaların büyük bölümünde antropometrik ölçümler kullanılmaktadır. Bu çalışmalar içinde farklı antropometrik ölçüm noktaları kullanılmış ve çok sayıda ölçümler alınmıştır. Yöntem olarak direkt ya da indirekt ölçüm metotları kullanılmaktadır. İndirekt 
Akı Abacı vd.| Antropoloji (40) (2020)

Tablo 10. Üst ekstremiteden alınan uzunluk ölçümlerinin tüm grup için 1,618 ile karşılaştırılmış analiz sonuçları

\begin{tabular}{ccccc}
\hline Ölçümler & Sağ taraf oranları & $\boldsymbol{p}$ & Sol taraf oranları & $\boldsymbol{p}$ \\
\hline Parmak ucu-dirsek / el bileği-dirsek & $1,70(1,63-1,82)$ & $<0,001^{1}$ & $1,70(1,62-1,79)$ & $<0,001^{1}$ \\
3. parmak /5. parmak & $3,22 \pm 0,154$ & $<0,001^{2}$ & $3,21 \pm 0,166$ & $<0,001^{2}$ \\
2. parmak / proksimal ilk iki boğum uzunluğu & $1,53 \pm 0,076$ & $<0,001^{2}$ & $1,50 \pm 0,057$ & $<0,001^{2}$ \\
3. parmak / proksimal ilk iki boğum uzunluğu & $1,51 \pm 0,06$ & $<0,001^{2}$ & $1,47(1,39-1,84)$ & $<0,001^{1}$ \\
4. parmak / proksimal ilk iki boğum uzunluğu & $1,53 \pm 0,068$ & $<0,001^{2}$ & $1,53 \pm 0,061$ & $<0,001^{2}$ \\
5. parmak / proksimal ilk iki boğum uzunluğu & $1,62(1,44-2,42)$ & $\mathbf{0 , 3 0 4}$ & $1,60 \pm 0,092$ & $\mathbf{0 , 2 4 9}^{2}$ \\
2. parmak / distal ilk iki boğum uzunluğu & $1,44 \pm 0,52$ & $<0,001^{2}$ & $1,42 \pm 0,047$ & $<0,001^{2}$ \\
3. parmak / distal ilk iki boğum uzunluğu & $1,45(1,01-1,61)$ & $<0,001^{1}$ & $1,44(1,37-1,59)$ & $<0,001^{1}$ \\
4. parmak / distal ilk iki boğum uzunluğu & $1,41 \pm 0,46$ & $<0,001^{2}$ & $1,41 \pm 0,048$ & $<0,001^{2}$ \\
5. parmak / distal ilk iki boğum uzunluğu & $1,38(1,28-2,00)$ & $<0,001^{1}$ & $1,38 \pm 0,066$ & $<0,001^{2}$ \\
\hline
\end{tabular}

${ }^{1}$ Tek Örnek Wilcoxon İşaret Testi, Medyan (Minimum-Maksimum)

${ }^{2}$ Tek Örnek t Testi, Ortalama \pm Standart Sapma

Tablo 11. Kadın üst ekstremitelerinden alınan uzunluk ölçümlerinin 1,618 ile karşılaștırılmış analiz sonuçları

\begin{tabular}{ccccc}
\hline Ölçümler (Kadın) & Sağ taraf oranları & $\boldsymbol{p}$ & Sol taraf oranları & $\boldsymbol{p}$ \\
\hline Parmak ucu-dirsek / el bileği-dirsek & $1,72 \pm 0,041$ & $<0,001^{2}$ & $1,71 \pm 0,039$ & $<0,001^{2}$ \\
3. parmak / 5. parmak & $3,24 \pm 0,175$ & $<0,001^{2}$ & $3,25 \pm 0,171$ & $<0,001^{2}$ \\
2. parmak / proksimal ilk iki boğum uzunluğu & $1,53 \pm 0,081$ & $<0,001^{2}$ & $1,50 \pm 0,057$ & $<0,001^{2}$ \\
3. parmak / proksimal ilk iki boğum uzunluğu & $1,52 \pm 0,050$ & $<0,001^{2}$ & $1,47(1,41-1,59)$ & $<0,001^{1}$ \\
4. parmak / proksimal ilk iki boğum uzunluğu & $1,53 \pm 0,054$ & $<0,001^{2}$ & $1,53 \pm 0,063$ & $<0,001^{2}$ \\
5. parmak / proksimal ilk iki boğum uzunluğu & $1,62(1,44-2,42)$ & $\mathbf{0 , 9 8 1 ^ { 1 }}$ & $1,60 \pm 0,092$ & $\mathbf{0 , 4 5 3}^{2}$ \\
2. parmak / distal ilk iki boğum uzunluğu & $1,44 \pm 0,048$ & $<0,001^{2}$ & $1,42 \pm 0,048$ & $<0,001^{2}$ \\
3. parmak / distal ilk iki boğum uzunluğu & $1,46 \pm 0,047$ & $<0,001^{2}$ & $1,45 \pm 0,056$ & $<0,001^{2}$ \\
4. parmak / distal ilk iki boğum uzunluğu & $1,41 \pm 0,044$ & $<0,001^{2}$ & $1,41 \pm 0,044$ & $<0,001^{2}$ \\
5. parmak / distal ilk iki boğum uzunluğu & $1,37(1,28-2,00)$ & $<0,001^{1}$ & $1,39 \pm 0,062$ & $<0,001^{2}$ \\
\hline
\end{tabular}

${ }^{1}$ Tek Örnek Wilcoxon İșaret Testi, Medyan (Minimum-Maksimum)

${ }^{2}$ Tek Örnek t Testi, Ortalama \pm Standart Sapma

Tablo 12. Erkek üst ekstremitelerinden alınan uzunluk ölçümlerinin 1,618 ile karşılaştırılmış analiz sonuçları

\begin{tabular}{ccccc}
\hline Ölçümler (Erkek) & Sağ taraf oranları & $\boldsymbol{p}$ & Sol taraf oranlar1 & $\boldsymbol{p}$ \\
\hline Parmak ucu-dirsek / el bileği-dirsek & $1,69 \pm 0,032$ & $<0,001^{2}$ & $1,68 \pm 0,037$ & $<0,001^{2}$ \\
3. parmak / 5. parmak & $3,19 \pm 0,122$ & $<0,001^{2}$ & $3,15 \pm 0,146$ & $<0,001^{2}$ \\
2. parmak / proksimal ilk iki boğum uzunluğu & $1,53 \pm 0,071$ & $<0,001^{2}$ & $1,49 \pm 0,056$ & $<0,001^{2}$ \\
3. parmak / proksimal ilk iki boğum uzunluğu & $1,50 \pm 0,071$ & $<0,001^{2}$ & $1,48(1,39-1,84)$ & $<0,001^{1}$ \\
4. parmak / proksimal ilk iki boğum uzunluğu & $1,52 \pm 0,084$ & $<0,001^{2}$ & $1,53 \pm 0,060$ & $<0,001^{2}$ \\
5. parmak / proksimal ilk iki boğum uzunluğu & $1,65 \pm 0,089$ & $\mathbf{0 , 0 4 4 ^ { 1 }}$ & $1,60 \pm 0,089$ & $\mathbf{0 , 3 8 1 ^ { 2 }}$ \\
2. parmak / distal ilk iki boğum uzunluğu & $1,43 \pm 0,058$ & $<0,001^{2}$ & $1,41 \pm 0,045$ & $<0,001^{2}$ \\
3. parmak / distal ilk iki boğum uzunluğu & $1,46(1,01-1,53)$ & $<0,001^{1}$ & $1,45 \pm 0,042$ & $<0,001^{2}$ \\
4. parmak / distal ilk iki boğum uzunluğu & $1,41 \pm 0,050$ & $<0,001^{2}$ & $1,42 \pm 0,053$ & $<0,001^{2}$ \\
5. parmak / distal ilk iki boğum uzunluğu & $1,39 \pm 0,523$ & $<0,001^{2}$ & $1,37 \pm 0,071$ & $<0,001^{2}$ \\
\hline
\end{tabular}

${ }^{1}$ Tek Örnek Wilcoxon İşaret Testi, Medyan (Minimum-Maksimum)

${ }^{2}$ Tek Örnek t Testi, Ortalama \pm Standart Sapma

antropometrik ölçümlerde; üç boyutlu lazer tarama, iki boyutlu fotografik değerlendirme ve radyolojik ölçüm metotları tercih edilmektedir. Direk antropometrik ölçümlerde ise; dijital kumpas, çift sürgülü kumpas, derinlik ölçüm aleti, deri kıvrımı ölçme aleti, açı ölçüm seti, mezura, boy ölçüm aleti, baskül gibi antropometrik ölçüm aletlerinden yararlanılmaktadır(Güzel, 2013). Biz de bu çalışmamızda digital kumpas, martin tip antropometre, kayan pergel, T cetveli, mezura ve normal cetvel kullandık. Yüz ile ilgili direkt antropometrik 
çalışmalar baş Frankfurt horizontal planda metot olarak belirlenen noktalardan alınarak yapilır. Bu tekniğin dezanataj1 ölçüm yapan kişinin ölçüm esnasında ölçüm aletinden dolayı oluşan hataların olabilmesi ve ölçümün diğer tekniklere oranla daha uzun süre almasıdır. Antropometrik çalışmayı yapacak olan araştırmacının ölçüm yapacağ1 tekniği belirlemeden önce iyi bir literatür taraması yapmalı, doğru aletleri seçmeli ve kısa sürede doğru ölçümle ulaşabileceği tekniği belirlemelidir. Ayrıca bu yöntemde belli antropometrik noktaların belirlenmesindeki zorluk ve özellikle yüz bölgesinden alınan ölçümlerin kişiye vereceği rahatsılıktan dolayı duyulan tedirginlik de zorluklardan bir bölümü olarak sayılabilir (Özkoçak, 2018).

Günümüzde insan sağlığını ilgilendiren tıp alanı gibi pek çok farklı alanda antropometrik ölçümler kullanılmaktadır (Kır vd., 2000). Tıp alanında özellikle beslenme ve büyüme durumunu değerlendirmek amaciyla boy, ağırlık ve baş çevresi başta olmak üzere birçok antropometrik ölçümler kullanılmaktadır. Bu ölçümlerin yanısıra anatomik yapı bozukluklarını saptayarak ve aynı zamanda genetik bozukluk veya hastalıkların tanınmasını kolaylaştırmak amacıyla yüz ölçümleri, göğüs çevresi ölçümleri, üst ve alt ekstremite ölçümleri yapılmaktadır. Daha detaylı antropometrik araştırmalarda ekstremite ölçümlerinin yanı sıra, üst kol orta çevresi, üst kol orta çevresi / baş çevresi oranı, deri kıvrımı kalınlıkları, üst kol kas alanı-üst kol yağ alanı ölçümleri ve vücut kas indeksi değerlendirmeleri yapılmaktadır (Sencer, 2012). Biz bu çalışmamızda, yüz ve ekstremite uzunluk ölçümleri üzerinden altın oran değerlendirmesi yaptık, ancak çevre ve doku kalınlık ölçülerini kullanmadik.

Estetik bilimi dahilinde geçen güzellik soyut bir kavramdır. Felsefe tarihi boyunca güzellik birçok kavramla ilişkilendirilmesine rağmen güzelliğin tanımını yapmak ve güzeli açıklamak oldukça zor olmuştur (Kesim vd., 2010; Çakmak, 2012). Güzellik kavramını inceleyen Platon, önce güzel ve iyi arasında bir benzerlik olduğunu ifade etmiş ve sonrasında bu iki kavramın aynı olduğunu ileri sürmüştür. İlerleyen süreç içerisinde ise bu kavramı matematiksel temellere dayandırmıştır. Platon'dan sonra Aristo'da güzellikte ölçünün gerekliliğinden bahsetmiş ve güzelliğin düzen, oran ve ölçü bütünlüğü içinde olabileceğini savunmuştur. Aristo'ya göre ise; estetik, bir şeyin bütünüyle parçaları arasinda bulunan matematiksel oranlarda saklı ve estetik düşünce bilimsel bir nitelik taşımaktadır (Bigalı, 1984). Anlaşıldığ1 üzere Antik dönemden günümüze beden güzellik ile ilişkilendirilmiş, sayılar ile de idealize edilmeye çalışılmıştır. Bunun sonucunda, ideal güzellik, ideal oran, ideal yüz oran1, ideal boy gibi kavramlar ortaya çıkmıştır. İdeal güzellik kavramını anlamamıza yardımcı olan güzellik ölçüsü olarak da bilinen kuram ise Altın
Oran Kuramı'dır (Ergenekon, 2002; Eşel, 2009; Öğgdül, 2010). Insan bedeninin farklı bölümlerinde altın oranın var olduğu öne sürülmüş olmasına rağmen günümüzde bu konuda yetersiz sayıda çalışma bulunmaktadır.

Yüz üzerinde yapılan antropometrik araştırmalarda çalışmanın amacına yönelik olarak farklı antropometrik noktalar kullanılmıştır. Ancak bu çalışmaların çok azı altın oranı araştırmaya yöneliktir. Hastürk (2014) çalışmasında yüz bölgesinde altın oran varlı̆̆ından söz etmiş ve var olduğu düşünülen bazı altın oranları şu şekilde ifade etmiştir: yüz boyu / yüzün genişliği, dudak-kaşların birleşim yeri arası / burun boyu, yüz boyu / çene ucu-kaşların birleşim yeri arası uzunluk, ağ1z genişliği / burun genişliği, burun genişliği / burun delikleri arası, göz bebekleri arası / kaşlar arası (Hastürk, 2014). Bu çalışmada oransal değerlerden bahsedilmiş olmasına rağmen rakamsal ölçümler yer almamaktadır. Biz de çalışmamızda, bu oranları referans aldık, martin tip antropometre ve kayan pergel kullanarak rakamsal olarak altın oran değerinin varlığını araştırdık. Seghers ve arkadaşlarının yaptığı bir çalışmada, Hastürk’ün çalışmasına benzer şekilde, yüzün boy uzunluğunun yüz genişliğine oranı, dudak ve kaşların birleşim yeri arası mesafenin burun uzunluğuna oranı, yüz uzunluğunun çene ucu ve kaşların birleşim yeri arası uzunluğuna oranının ve burun genişliğinin burun delikleri arası mesafeye oranının altın orana eş değer oldukları ifade edilmiştir. Ayrıca aynı çalışmada bir göz genişliğinin yüz genişliğinin beşte biri ve bir interkantal mesafeye eşit olması gerekliliğinden söz edilmektedir (Seghers vd., 1964) Bizim yüz bölgesi sonuçlarımızda da benzer şekilde Fizyonomik yüz yüksekliği (tr-gn) / Yüz genişliği $(z y$-zy), Yüz genişliği (zy-zy) / Üst yüz yüksekliği (n-sto) ve Saçların başlama noktası-subnasale (tr-sn) / Üst yüz yüksekliği (n-sto) ölçümlerinde 1,618 değerine yakın sonuçlar bulunmuştur. Yüz üzerinde yapılan altın oran araştırmalarından biri de kulak üzerinde yapılan antropometrik ölçümlerdir. Romm ve ekibinin (1992) yaptığ1 çalışmada kulağın en mesafesinin boyunun yaklaşık yarısı kadar olduğu belirtilmiştir.

Eşel'in (2009) "güzellik oranı" olarak belirlediği değerler altın oran ile benzerlikler göstermektedir. Burun kökü (nasion) ve burun alt ucundan (subnasale) geçen yatay doğruların yüzü üç parçaya böldüğü, burun uzunluğu ile kulak uzunluğunun eşit olması, burun alt yüzeyinin ortalama bir buçuk kat genişliğinin ağız genişliğine denk gelmesi gibi oranlar altın oranla ilişkilendirmiştir (Eşel, 2009). Bir başka yüz çalışmaları yapan araştırıcı Murali'nin çalışmasına göre belirlediği altın oran değerlerini şu şekilde ifade etmiştir: yüz uzunluğu / yüz genişliğ̣i, dudaklar ile kaşların birleştiği yer / burun uzunluğu arasındaki mesafe, yüz uzunluğu / çenenin ucu ile kaşların birleştiği yer arasındaki mesafe, burun delikleri arasındaki mesafe / burun genişliği, 
pupiller arası mesafe/ kaşlar arasındaki mesafe değerleri altın oranı vermektedir. Bir başka kaynakta ise altın oranın yüz uzunluğu / genişliği, dudak-kaş/ burun uzunluğu, yüz uzunluğu/ çene-kaş, ağız genişliği/ burun genişliği, burun genişliği / burun delikleri arası genişlik, pupiller arası mesafe/ kaşlar arası mesafeler bulunduğu iddia edilmektedir. Ayrıca bu değerin, bilim adamları ve sanatçılar tarafindan belirlenen "ideal insan yüzü" anlamına geldiği de belirtilmektedir. Biz de bu çalışmada yüz bölgesinde belirtilen kaynaklardaki altın oranları araştırdık. Yüz üzerinde altın oran araştırması yaparken 1,618'e yakınlık anlamında karşılaştırma yaptık ve sonuçlarımızı literatür sonuçları ile karşılaştırdık. Kadınlarda (tr-gn)/(zy-zy) değeri 1,601 $\pm 0,097 \quad(p=0,260)$, $(z y-z y) /(s t o-n)$ değeri $1,590 \pm 0,12 \quad(p=0,278)$ ve $(t r-s n) /$ $(s t o-n)$ değeri $1,66(0,91-1,87)(p=0,103)$ olarak bulunmuş ve altın orana yakın olarak değerlendirilirken erkeklerde, $(t r-g n) /(3 y-s y)$ değeri 1,576 (1,37-2,46) $(p=0,064)$, (tr$g n) /(t r-s n)$ değeri $1,579(0,97-2,15) \quad(p=0,110),(z y-z y) /$ (sto-n) değeri 1,64 (0,96-1,94) $(p=0,248),($ tr-gn $) /($ tr-sn $)$ değeri $1,57(0,97-2,15) \quad(p=0,110)$ ve $(t r-s n) /(s t o-n)$ değeri $1,66(0,96-2,41) \quad(p=0,379)$ olarak bulunmuş ve 1,618 'e olan yakınlıkları anlamlı olarak değerlendirilmiştir.

Günümüzde yüz güzelliğinin önem kazanması ile, güzel olmanın hayatın birçok alanında avantaj sağladığı savunulmakta (Langlois vd., 2000) ve güzel bir yüze sahip bireylerin daha dişa dönük, mutlu ve başarılı olduğu iddia edilmektedir (Dion vd., 1972). Emmanuel ve ekibi (2012), yüzde simetri ifadesini gündeme getirmiş, yüzdeki simetrinin çekici yüzlerin bir özelliği olduğunu ve bu özelliğin estetikte kullanılması gerektiğini ifade etmiştir. Kiekens ve ekibi (2008) yaptıkları çalışmada, yüz estetiği ve altın oranlar arasında varsayılan ilişkiyi analiz etmiş, 64 genç erişkin bireyin fotoğraflarını 76 kişinin değerlendirmesine sunmuş ve sonuçları 0'dan 100'e kadar görsel analog ölçeği ile kullanarak değerledirmelerini istemişlerdir. Toplam 19 altın orandan 4'ünün puanlamalarında anlamlı bir korelasyon olduğu bulunmuştur. $\mathrm{Bu}$ oranların ise yüz estetiği algilanmasının sadece küçük bir kısmını oluşturduğu yorumunu yapmışlardır. Ek olarak bu çalışmada anlamlı korelasyon bulunduğu ifade edilen ölçümler $n$-sto / stogn, n-gn / n-sto, sn-gn / sto-gn, sn-gn / sto-gn'dir (Kiekens vd., 2008). Bizim yaptığımız çalışma ile bu sonuçları karşılaştırdığımızda Fizyonomik yüz yüksekliği (tr$g n)$ / Morfolojik yüz yüksekliği (n-gn), Morfolojik yüz yüksekliği (n-gn) / Üst yüz yüksekliği (n-sto), Saçların başlama noktasi-subnasale (tr-sn) / Üst yüz yüksekliği (n-sto), Ağız genişliği / burun genişliği ölçümlerinin her iki çalışmada da kullanıldığı tespit edilmiştir. Ancak iki çalışmanın sonuçları karşılaştırıldığında n-gn / n-sto oranları bakımından benzerlik gösterdiği tespit edilmiştir.

Pamela ve ekibi, yüz çekiciliğini ortaya koymak için yaptıkları çalışmalarında, yüz uzunluğu ve genişliğini ölçerek oran değerlerini ortaya koymuşlardır. Bu çalışmada, yüzün göz-ağız mesafesinin yüz uzunluğunun \%36's1 ve interoküler mesafenin yüz genişliğinin \%46's1 değerine ulaştığında, bu ölçeğin en uygun çekiciliği gösterdiğini ortaya koymuşlardır. Mutlak çekicilik seviyesinin ise yüz özelliklerindeki farklılıklarla değişse bile optimum uzunluk ve genişlik oranları sabit kaldığını, optimal "altın oranın" ortalama bir yüzün oranlarına karşl11k geldiğini ortaya koymuşlardır (Pamela vd., 2010). Bu çalışmada aynı zamanda cinsiyet yönünden altın oran araştırması yapmışlar ve vertikal yönde benzer ancak sagittal yönde farklılıklar olduğunu bulmuşlardır. Ayrıca dental ark, üst ve alt çene arasında orta düzeyde sapmaya sahip bireylerin yüz estetiklerinin, kız ve erkek bireylerde altın oran bakımından farklılık gösterdiğini ifade etmişlerdir. Buna göre tedavi görmemiş postpubertal kız ve erkek bireyler arasındaki farklılıkların ortodontistlerin teşhis ve tedavi planlamasında yol gösterebileceğini ifade etmiştir (Kaya Şengül, 2016). Biz çalışmamızda kız ve erkek bireylerin altın oran değerleri arasında benzerlik gösterdiğini tespit ettik.

Güngörmüş (2008), çalışması sonucunda elde ettiği veriler 1şığında canlı bir bireyden alınan iç kantal uzaklık, yüz genişliği, bigonial genişlik, trichion-gnathion uzunluğu, dudak genişliği, üst yüz yüksekliği ve tüm yüz yüksekliği ölçülerinin bireylerin fotoğrafları üzerinden de alınabilineceği sonucuna varılmış olup, diğer ölçülerden ise; dış kantal uzaklık, burun genişliği, burun yüksekliği ve kulak yüksekliği ölçülerinin ise fotoğraf üzerinden alınamayacağı sonucuna varmışlardır. Bu çalışmanın ölçülerini bizim ölçümlerimiz ile karşılaştırdığımızda 4 ölçümün ortak olduğunu fark ettik. Yapılan çalışmada

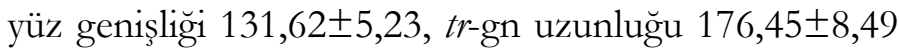

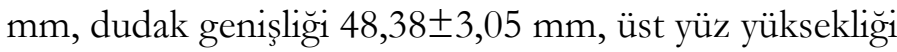
$73,46 \pm 4,09 \mathrm{~mm}$, tüm yüz yüksekliği $114,17 \pm 6,33 \mathrm{~mm}$ iken, bizim çalışmamızda yüz genişiliği $117,22 \pm 7,23$ $\mathrm{mm}$, ağız genişliği $50,23 \pm 48,6 \mathrm{~mm}$, tr-gn uzunluğu olan fizyonomik yüz yüksekliği 187,11 $15,95 \mathrm{~mm}$, dudak genişliği $50,23 \pm 48,61 \mathrm{~mm}$, üst yüz yüksekliği $73,15 \pm 7,61 \mathrm{~mm}$ ve tüm yüz yüksekliği olan ve çalışmamızda morfolojik yüz yüksekliği dediğimiz oran ise $122,06 \pm 6,02 \mathrm{~mm}$ olarak bulunmuştur. Üst yüz yükseklik değerlerinin ise benzer olduğu belirlenmiştir (Güngörmüş, 2008).

Altın oranın yüz estetiğinde önemini vurgulayan çalışmalar bulunmasına ragmen, altın oranın geçerli olmadığ çalışmalar da söz konusudur (Habbema, 2004, Jefferson, 2004). Nakajima ve Yanagisawa (1985) Japonlarda frontal planda alınmış yüz fotoğraflarında altın oranı incelemiş ve altın orandan ziyade 1,143 oranı bulunduğunu belirlemişlerdir. Fidancıoğlu ve ekibi (2010) ergenlik dönemindeki Türk bireylerde yüz çekiciliğini değerlendirmiş ve yüzde altın oran 
bulgusunun yüz güzelliğine etkisini incelemişlerdir. Buna göre; altın oran değerlerine sahip bireylerin çekicilik ve güzellik anlamında kabul etmesini sadece $\% 25$ oranında desteklemektedir. Fidancıoğlu ve ekibi (2010) ile bizim çalışmamızda ortak olarak yer alan altın oran değerleri farklı antropometrik nokta isimleri ile yer almakla beraber, aynı uzunlukları ifade etmektedir. Buna göre trme / tr-al arası mesafeyi Fidancıoğlu ve ekibi (2010) 1,68 $\pm 0,06$ olarak ifade ederken, bizim çalışmamızda bu değer $1,55(0,97-2,69)$ olarak bulunmuştur. Her iki çalışmada ortak olarak değerlendirilen bir başka ölçüm ise $c h$-ch / al-al oranıdır. Bu değer bizim çalışmamızda 1,40 (1,151,95), Fidancıoğlu ve ekibinin (2010) çalışmasında ise 0,77 $\pm 0,07$ olarak belirlenmiştir.

Yüzde altın orana dayanılarak geliştirilen teknikler, bugün yüz estetiğinde kullanılmaktadır. Bunların başında Baund'un geliştirdiği Sirküler sektor analiz gelmektedir. Bu çözümlemede trchion'dan tragus'u birleştiren hat ile yüzün önünde yarım çember çizilir. Bu yarım daire burun ucu ile çene'den geçer. Bunun gibi kulakta tragus; trichion, nasion ve menton birleşince aralarında açı oluşmakta, bu açılar birbirlerine oranlandığında altın oran1 vermektedir (Pamela vd., 2010).

Al Marzok ve ekibi (2013), Malezya popülasyonunda bulunan farklı gruplarda yüz görünümlerini incelenmiş, bu gruplar arasinda altın oran ile ilgili anlamlı sonuç bulunmadığını ifade etmişlerdir. İnceledikleri popülasyonda sadece \%17,1’i normal yüz ölçülerine sahip iken, nüfusun çoğunluğunun kısa yüze $(\% 54,5)$ sahip olduklarını ve altın orana uyum göstermedikleri sonucuna varmışlardır (Al-Marzok vd., 2013). Bizim yaptı̆̆ımız çalışmada ise fizyonomik yüz yüksekliği dediğimiz trichion ve gnathion arası uzunluğumuzun bi zigomatik olarak ifade ettiğimiz yüz genişliğine oranın ortalamas1 1,59 çıkmışır $(p=0,024)$. Yüz genişliğinin üst yüz yüksekliği dediğimiz oranın ortalamas1 1,613 $(\phi=0,752)$ altın orana benzerlik bağlamında anlamlı olarak değerlendirilmiştir. Saçların başlama noktasısubnasale arası mesafenin üst yüz yüksekliği oranının ortalaması ise 1,660 $(p=0,071)$ olup altın oran açısından benzer olarak bulunmuştur.

Üst ekstremite bölgesinden yapılan birçok antropometrik çalışma mevcut olmasına rağmen literatürde kendi sonuçlarımızı karşılaştırabileceğimiz altın oran çalışmasına rastlamadık. Ancak uzunluk ölçülerimizi bazı antropometrik çalışmalar ile karşılaştırdık. Özlem ve arkadaşlarının el üzerinde yaptığ çalışmada 3. parmak uzunluğu sağ tarafta 72,2 \pm $1,23 \mathrm{~mm}$ sol tarafta $71,7 \pm 1.23 \mathrm{~mm}$ olarak bulmuşlardır. Bu sonuçlar bizim çalışmamızda tüm grupta sağ taraf 3 . parmak uzunluğu 76,62 $\pm 5,62 \mathrm{~mm}$ ve sol taraf 3. parmak uzunluğu 76,5 $\pm 5,7 \mathrm{~mm}$ olarak bulunmuştur (Özlem vd., 2018). Her iki çalışmada bu değerlerin birbirine yakın olduğu söylenebilir.
Sencer (2012), çalışmasında erkeklerde el orta parmağın bir kompartman olarak bazı vücut proporsiyonlarına oranlarını incelemiş, orta parmağın bir kompartman olarak kendisi ile devamll1tk göstermeyen, burun uzunluğu, kulak uzunluğu, ağ1z genişliği, el bileği genişlikleri gibi insanın kendi orta parmak uzunluklarının yaklaşık olarak yarısına eşit olduğu sonucunu bulmuştur. Sencer'in (2012) ölçümleri ile bizim sonuçları karşılaştırdığımızda Sencer'in yaptı̆̆ çalışmada, orta parmak uzunluğunu, yüz yüksekliğii, ağız

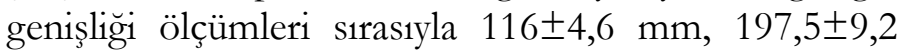
$\mathrm{mm}$ ve $57 \pm 4,6 \mathrm{~mm}$ bulmuştur. Bizim çalışmamızda ise sağ taraf 3. parmak uzunluğu $76,62 \pm 5,62 \mathrm{~mm}$ ve sol taraf 3. parmak uzunluğu 76,5 $\pm 5,7 \mathrm{~mm}$ olarak bulunmuştur. Bu sonuçların karşılaştırması sonrasında bizim sonuçlarımızdaki değerlerin daha düşük olduğu tespit edilmiştir.

Ladda ve ekibi (2013) üst ekstremite ölçüm çalısmasında parmakların antropometrik ölçümlerinden onklüzyon dikey boyutunu belirlemek için yeni bir teknik geliştirmiştir. Buna göre erkeklerde bu boyutu belirlemek için en iyi parametre işaret parmağ1 iken, kadinlarda bu parametrenin serçe parmağı olduğu tespit edilmiştir. Erkeklerde işaret parmağ1 uzunluk ortalamas $71,6 \pm 4,3 \mathrm{~mm}$ ve serçe parmak uzunluğu ise $61,5 \pm 3,7 \mathrm{~mm}$ kadinlarda ise sirasiyla $65,9 \pm 4,1 \mathrm{~mm}$ ve $56,3 \pm 3,3$ mm'dir. Bizim çalışmamızda sağ taraf işaret parmak uzunluğu (2. parmak) 70,19 $\pm 5,19 \mathrm{~mm}$ ve sol

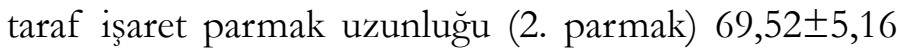
$\mathrm{mm}$ olarak bulunmuştur. Ek olarak sağ taraf işaret parmak uzunluğu (5. parmak) $57,99 \pm 4,88 \mathrm{~mm}$ iken sol taraf işaret parmağ 1 (5. parmak) 57,81 $\pm 5,04 \mathrm{~mm}$ olarak bulunmuştur. Her iki çalışmada bu ölçümler bakımından benzerlik gösterdiği tespit edilmiştir.

\section{Sonuç}

Altın oran ifadesi uzun yıllar boyunca farklı alanlarda kullanılmış ve sayısal olarak varlığından söz edilmiştir. Gerçekleştirilen birçok araştırmada, bu sayısal oranın doğal olarak zaten var olduğundan ve yapıların özelliklerinin belirlenmesinde etkili olduğundan bahsedilmiştir. $\mathrm{Bu}$ oran, insan vücudunda yapılan antropometrik ölçümler üzerinde de şaşırtıcı olarak karşımıza çıkabilmektedir. Sanat alanında birçok sanatçının da insan vücudunu tanımlarken ve insanların kullanımına sunulan tasarımlar ortaya koyarken bu oranı kullandığ1 görülmektedir. Zaten insan doğasında var olan bu oranın, antropometrik çalışmalar sonrasında ortaya çıkan veriler temel alınarak kullanılması sonucunda, daha ergonomik ve ruhsal olarak da güzel olarak beğenilen eserler ortaya konulacaktır.

Biz bu çalışmamızda yüz, üst ekstremite ve gövde bölgelerinden alınan antropometrik ölçümler arasında altın oran değerine yakınlığı araştırdık. Belirlediğimiz 
parametreler mevcut literatür eşliğinde ortaya konmuş olup, bu parametrelerin yanı sıra kendi belirlediğimiz bazı antropometrik ölçümler arasındaki oranların da 1,618 değerine yakınlığını inceledik. Tüm ölçümleri Martin tip antropometre, antropometre pergeli, dijital kumpas ve T cetveli kullanarak yaptık. Gövde ve üst ekstremite referans noktalarını belirlemek güç olmamakla beraber, bazı kişilerde yüz referans noktalarını belirlemek kolay olmadı ve bu kişileri çalışma dışı bıraktık. Tüm ölçümleri \%10 kadarında ikili ölçümler yaparak istatistiksel olarak değerlendirmelerini yaptık. Bizim ölçüm sonuçlarımızda; yüz bölgesinde altın oran değerini belirlemiş olmamıza rağmen, gövde bölgesinden alınan ölçümler üzerinde yapılan altın oran değerleri arasında her iki cinste de altın orana yakınlık tespit edilmemiştir. Üst ekstremitede yapılan antropometrik ölçümler sonrasında altın oran değerlendirme sonuçlarında ise 5. parmağa ait oransal değerlerin 1,618'e yakınlığ1 belirlenmiş, ancak diğer parmaklarda böylesi bir sonuç elde edilmemiştir. Ayrıca her iki cinste de parmak boyları arasında bir altın oran değerine rastlanmamıştır.

Bu çalışmanın sonucunda elde ettiğimiz sonuçların veri sayısı artışına bağlı olarak değişsebileceği göz önünde bulundurularak, mevcut sonuçların bilim ve sanat alanlarında faydalı olacağını ve daha sonra yapılacak olan altın oran çalışmaları için öncü nitelik taşıyabileceğini düşünmekteyiz.

\section{Kaynakça}

Abbas, O. L, Kürkçüoğlu, A, Pelin C., ve Yazıcı, A. C. (2015). Anthropometric measurement and analysis of the lower face in Turkish rhinoplasty patients. European Journal of Plastic Surgery, 38, 449-458. https://doi.org/10.1007/s00238-0151135-9

Al-Marzok, M. I., Majeed, K. R. A., ve Ibrahim, I. K. (2013). Evaluation of maxillary anterior teeth and their relation to the golden proportion in malaysian population. BMC Oral Health 13(9). https://doi.org/10.1186/1472-6831-13-9

Bergil, M. (1993). Doğada bilimde sanatta altın oran. Arkeoloji ve Sanat Yayınları.

Bigalı, Ş. (1984) Resim sanatı, 2. baskı. Şafak Matbaası.

Brownlee, J. (2015, 13 Nisan). The Golden Ratio: Design's biggest myth. Fast Company. https://www.fastcompany. $\mathrm{com} / 3044877 /$ the-golden-ratio-designs-biggest-myth

Çakmak, S. (2012). Gösteren ve gösterilen boyutlaryla Türkçede güzellike kavramı üzerine. Atatürk Üniversitesi Türkiyat Araştırmaları Enstitüsü Dergisi, (48), 17-40. https://doi.org/10.14222/ Turkiyat1119

Deviren, D. (2010). Altın oran ve grafik sanatlarda kullanımı. Yayımlanmamış Yüksek lisans tezi. Haliç Üniversitesi, Sosyal Bilimler Enstitüsü, İstanbul.

Dion, K. Berscheid, E., Walster, E., (1972). What is beautiful is good. Journal of Personality and Social Psychology, 24(3), 285-290. https://doi.org/10.1037/h0033731

Prokopakis, E. P., Vlastos, I. M., Picavet, V., Nolst Trenite, G.,
Thomas, R., Cingi, C., ve Hellings, P. (2012). The golden ratio in facial symmetry. Rhinology, 51(1), 18-21. https://doi. org/10.4193/Rhin12.11

Ergenekon, B. (2002). Estetik cerrahiye bașvurmann kültürel nedenleri. Yayımlanmamış doktora tezi. Ankara Üniversitesi, Sosyal Bilimler Enstitüsü, Ankara.

Eşel, E. (2009). Güzellik ve cinsel çekiciliğin biyolojik temelleri, Bilim ve Ütopya, 181, 48-49.

Fidancioğlu, A., (2010). Ergenlik dönemindeki türk bireylerde yüz estetiğinin değerlendirilmesi. Yayımlanmamış doktora tezi. Selçuk Üniversitesi, Sağlık Bilimleri Enstitüsü, Konya.

Güngörmüş, S. (2008). Insanyü̈ü ve fotoğraflarndan alnnan antropometrik ölçülerle kimlike tespiti ve cinsiyet tayini. Yayımlanmamış yüksek lisans tezi. Ankara Üniversitesi, Sosyal Bilimler Enstitüsü, Ankara.

Güzel, E. (2013). Kültürel bağlamda kadnn ve güzellik: Türkiye'de bir iktidar alan olarak elitler üzerinden güzellik anlayısına ve bir tüketim nesnesine dönüsen kadın sorununa bakıș. Yayımlanmamıș doktora tezi. Yeditepe Üniversitesi, Sosyal Bilimler Enstitüsü, İstanbul.

Habbema, L. (2004). Facial esthetics and patient selection. Clinics in Dermatology, 22(1), 14-7. https://doi.org/10.1016/j. clindermatol.2003.12.032

Hastürk, E. Y. (2014) Antropometrik verilerde altın oran. Mesleki Bilimler Dergisi, 3(2), 173-177.

Jefferson, Y. (2004). Facial beauty--Establishing a universal standard. International Journal of Orthodontics (Milwaukee, Wis.), 15(1), 9-22.

Kaya Şengül, D., ve Rübendüz, M. (2016). Yüz estetiğinin altın oran ve cinsiyet yönünden değerlendirilmesi. http://dergi.dentistry.ankara.edu.tr/wp-content/ uploads/sites/97/2019/01/113-Y\%C3\%9CZESTET $\%$ C 4\%B $\% \% C 4 \% 9 \mathrm{E} \% \mathrm{C} 4 \% \mathrm{~B} 0 \mathrm{~N} \% \mathrm{C} 4 \% \mathrm{~B} 0 \mathrm{~N}-$ ALTIN-ORAN-VE-C $\%$ C 4\%B ONS $\%$ C 4\%BOYETY\%C3\%96N\%C3\%9CNDEN.pdf

Kesim, S. Kar, A., ve İnceoğlu, Y. (2010). Plastik cerrahi, “Tanrım beni baştan yarat!.." metaforunu mümkün kılabilir mi?. Y. İnceoğlu ve A. Kar (ed.) içinde, Dişilik, güzellik ve siddet sarmalinda kadin ve bedeni, Ayrıntı Yayınları.

Kır, T., Ceylan S., ve Hasde, M. (2000). Antropometrinin sağl1k alanında kullanımı. Türkiye Klinikleri T⿰р Bilimleri Dergisi, 20(6), 378-384.

Kiekens, R. M. A., Kuijpers-Jagtman, A. M., A. van 't Hof, M. A., van 't Hof, B. E., ve Maltha, J. C. (2008). Putative golden proportions as predictors of facial esthetics in adolescents. American Journal of Orthodontics and Dentofacial Orthopedics, 134(4), 480-483. https://doi.org/10.1016/j.ajodo.2006.10.041

Kürkçüoglu, A., Abbas, O. L., Ayan, D. M., Baykan, R., Demirkan, E., Özkan, Ö., Özkubat, I., ve Şimşek, M. (2016). Comparison of objective and subjective assessments for perception of facial symmetry. Anatomy, 10(2), 94-98. https://doi. org/10.2399/ana.16.012

Ladda, R., Bhandari, A. J., Kasat, V. O., ve Angadi, G. S. (2013). A new technique to determine vertical dimension of occlusion from anthropometric measurements of fingers. Indian Journal of Dental Research, 24(3), 316-320. https://doi. org/10.4103/0970-9290.117993

Langlois, J. H., Kalakanis, L., Rubenstein, A. J., Larson, A., Halam, 
M., ve Smooth, M. (2000). Maxims or myths of beauty? A metaanalytic and theoretical review. Psychological Bulletin, 126(3), 390-423. https://doi.org/10.1037/0033-2909.126.3.390

Nakajima E,Yanagisawa M. (1985). The Japanese sense of beauty and facial proportions. I. The facial characteristics of people with malocclusions. Quintessence International, 8, 553-557.

Öğdül, R. (2010). Sayılarla belirlenen güzel beden. Sanat Dünyamıそ, $115,4-5$.

Özkoçak, V. (2018). Antropometric techniques used for determining aesthetic anatomical and anthropological structure. Eurasian Academy of Sciences Eurasian Art Humanities Journal, (9), 30-38.

Pallett, P. M., Link, S., Lee, K. (2010). New “golden” ratios for facial beauty. Vision Research, 50(2), 149-154. https://doi. org/10.1016/i.visres.2009.11.003

Chatrath, P., de Cordova, J., Reza Nouraei, S. A., Ahmed, J., ve Saleh, H. A. (2007). Objective assessment of facial asymmetry in rhinoplasty patients. Archives of Facial Plastic Surgery, 9(3), 184-187. https://doi.org/10.1001/archfaci.9.3.184

Porter, J. P., ve Olson, K. L. (2001). Anthropometric facial analysis of the African American woman. Archives of Facial Plastic Surgery, 3(3), 191-197. https://doi.org/10.1001/archfaci.3.3.191

Ricketts, R. M. (1982). Divine proportion in facial esthetics. Clinical Plastic Surgery, 9(4), 401-422.

Romm, S. (1992). The changing face of beauty. Mosby Year Book.

Seghers, M. J, Longacre J. J, ve deStefano, G. A.(1964). The golden proportion and beauty. Plastic Reconstructive Surgery, 34(4), 382-386. $\quad$ https://doi.org/10.1097/00006534-196410000$\underline{00007}$

Sencer, Ö. (2012). Genç erișkin erkekelerde el orta parmăğnm bir kompartman olarak baz? vücut proporsiyonlarna oranlar. Yayınlanmamış doktora tezi. Trakya Üniversitesi Sağllk Bilimler Enstitüsü, Edirne.

Uzun, Ö., Yeginoğlu, G., Kalkışım, Ş. N., Ertemoğlu Öksüz, C., Zihni, N. B. (2018). Evaluation of upper extremity anthropometric measurements in terms of sex estimation. International Journal of Research in Medical Sciences, 6(1), 42-50. https://doi.org/10.18203/2320-6012.iirms20175709

Varlık, S. K., Demirbaş, E., ve Orhan, M. (2010). Influence of lower facial height changes on frontal facial attractiveness and perception of treatment need by lay people. The Angle Orthodontist, 80(6), 1159-1164. https://doi. org/10.2319/032509-176.1

Wahl, N. (2006). Orthodontics in 3 millennia. Chapter 7: Facial analysis before the advent of the cephalometer. American Journal of Orthodontics and Dentofacial Orthopedics, 129(2), 293298. https://doi.org/10.1016/j.ajodo.2005.12.011

Wang, Z. M, Pierson, Jr, R. N., ve Heymsfield, S. B. (1992). The fivelevel model: a new approach to organising body composition research. The American Journal of Clinical Nutrition, 56(1), 19-28. https://doi.org/10.1093/ajcn/56.1.19

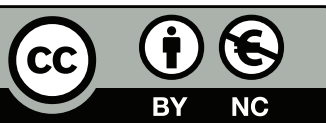

2020. Telif hakları yazar(lar)a aittir.

Bu makale Creative Commons Atıf-GavriTicari 4.0 Uluslararas1 (CC BY-NC 4.0) lisansının hüküm ve şartları altında yayımlanan açık erişimli bir makaledir. 